EEJ 11 (1) (2021) 71-78
UNNES
English Education Journal
htt//journal.unnes.ac.id/sju/index.php/eej

\title{
Error Analysis of Libyan Students' Use of Derivational Morphemes
}

Emran Ali Mohammed Alareefi ${ }^{1 凶}$, Anggani Linggar Bharati $^{2}$, Fahrur Rozi $^{2}$

1. Al-Mergib University, Libya

2. Universitas Negeri Semarang, Indonesia

\begin{abstract}
Article Info
Abstract

Article History:

Word formation occurs when we want to form new meaning, word class, and Accepted 27

September 2020

Approved 07

December 2020

Published 15 March

2021

Keywords:

Errors analysis, and

Derivational

Morphemes grammatical need. Morpheme is defined as the smallest meaningful unit of a language. This study to purpose to explain the errors that Libyan students made in using derivational morphemes, to explain why they make such errors and to find the solutions to overcome these errors. Research design in this study is qualitative research. Data in the form of quotes from documents, field notes, and interviews or excerpts from videotapes, audiotapes, or electronic communications are used to present the findings of the study. Based on the findings and discussion, the conclusion of this research as follows: The errors made by Libyan students in Semarang city in using derivational morphemes is varied from one student to another student, from the omission, addition, misordering and misformation, about the prefix and suffix. The contribution made to this study is by knowing the number of errors that occur in Libyans in English.
\end{abstract}




\section{INTRODUCTION}

Word formation occurs when we want to form new meaning, word class, and grammatical need. Meaning in this sense is to form new meaning from the previous one, like the word characteristic is created by adding the suffix -istic to the base character. The meaning of the word becomes the opposite of the meaning of the base word. The word means "having some character".

Word class is to changing the part of speech, example the word characteristic. The suffix -istic change the part of the speech from a noun "character" to be an adjective "characteristic". Then the grammatical is to indicate syntatic or semantic relations between different words in a sentences, like in waits. Morpheme -s shows agreement with the subject of the verb (both are third person singular).

In the process of word formation, there are two functions; derivational and inflectional functions. Derivational function is to form a new word with the new meaning and it also can change the part of speech (word class) of root. The derived word is often of a different word class from the root. Based on the statement above, derivational have any characteristic: a) in many case, but not all, derivational suffixes changes the part of speech of the word. The noun act becomes an adjective by addition of $i v e$, and to the adjective active we could add -ate, making it verb activate. b) typically occur before inflectional suffixes, example in chillier. The derivational suffix $-y$ comes before the inflectional -er. c) the words with which derivational suffixes combine are an arbitrary matter. To make a noun adornment from the verb adorn we must add the suffix -ment and no other suffix will do, whereas the verb fail combines only with -ure to make a noun failure.

To learn a second language is not easy thing, this shown by professional linguists and scholars point of views during their long experience and hard-working in this field because the learner is going to know a lot of new words and expressions of those people language grammatical structure. The English language linguistics as general and especially morphology which the researchers are going to talk about in this study includes a lot of elements. In order to get proficient linguistic performance, you should take long time to learn. Language is an essential communication tool for human life.

Morpheme is defined as the smallest meaningful unit of a language Words are made up of morphemes. The morphemes which can meaningfully stand alone are called free morphemes while the morphemes such as -er and $-\mathrm{s}$, which cannot meaningfully stand alone are called bound morphemes. Bound morphemes must be attached to free morphemes. Bound morphemes are also called affixes which can be classified into prefix, infix, and suffix. English only has two kinds of bound morphemes namely prefixes and suffixes. There are not infixes in English. Boun morphemes are classified into two namely derivational and inflectional morphemes. This article tries to discuss derivational morphemes.

These morphemes are complicated so that understanding what derivational morphemes are is important Therefore, we must be able to master the language and its elements such as vocabulary, structure, and so forth. The language itself consists of two aspects namely form and meaning. In relation to meaning, the smallest meaningful unit in language is morpheme Also this problem associated with the effort of the learner and his $\backslash$ her existing around those who have full English experience. (Muctar, 2007).

Added to that, there are there many big problems; a foreign Language learner shall face in study this major aspect of Language linguistics in his/her country as a second language. For instance the following types of problems: derivational morphemes, some exceptional in English morphemes. Forming new words refers to the ways in which new words are created and become part of the language. Forming new words from the existing words by adding affixes. Affixes is a common way of creating new words in any language especially in English. English has added the attentive suffix $-e r$ to the prepositions $u p$ and 
down to create the nouns upper and downer to refer to phenomena that lift or dampen spirit. Commonly -er is added to a verb (V) to create a word with the sense "one who V's": Singer "one who sings"; Writer "one who writes" and so on (Robert, 2014).

The differences between derivational and inflectional morphology are somewhat ambiguous to explain in some languages. As mentioned above, bound morphemes consist of inflectional and derivational morphemes. Inflectional morphemes are those which do not create new meaning. These morphemes never change the syntactic category of the words or morphemes to which they are attached. They only refine and give extra grammatical information about the already existing meaning of words which they are attached to (Akande 2001).

With morphology the students can learn about grammar and structure of English. To understand how the shape changes in a word, the writer may understand the process of changing the word. The term morphology is Greek and made of morp- meaning 'shape, form', and -ology which means 'the study of something'. Affix morphemes can be divided into two major functional categories, namely derivational morphemes and inflectional morphemes (Crowley, 2005).

Morphology is the study of word formation, including the ways new words was coined in the languages of the world, and the way forms of words are varied depending on how they are used in sentences (Lieber, 2009). In the process of word formation, there are some interesting words in English which lead the researcher to conduct this researcher. For example, the rule of suffixes -er which means a person who does whatever the verb means. Some words need to be multiplied in their last letter and added with -er when there is only three letters within the word (one vocal letter between two consonants), such as „,sit" becomes ,sitter or „cut" becomes „,cutter" In another condition, if there is a word which is ended in vocal / $e /$, it only needs suffixes $-r$, such as „love $e^{\text {ee }}$ becomes „lover"e or „lie ${ }^{\text {ee }}$ becomes „lier"e (John, 2008).
Wulandari's (2014) research entitled a morphologycal analysis of derivational suffixes in short stories.enjoyment is the word that formed from the base morpheme "enjoy" and the bound morpheme suffix "-ment". The results of this study were from 205 data, the researcher found four forms of derivational suffixes, the first was noun 47 data that consists -ance 4 data or $1.95 \%$, -ence 1 datum or $0.48 \%$, -ation 5 data or $2.43 \%$, -ment 7 data or $3.41 \%$, -ion 10 data or $4.87 \%$, -ness 15 data or $7.31 \%$, and -ity 1 datum or $0.48 \%$. Second is verb 1 datum that consists ize 1 datum or $0.48 \%$. Third is adjective 38 data that consists -able 5 data or $2.43 \%$, -ful 9 data or $4.39 \%$, -less 12 data or $5.85 \%$, -al 4 data or $1.95 \%$, and -ous 6 data or $2.92 \%$ ). Fourth is adverb 119 that consist -ly 119 data or $58.04 \%$.

This study was entitled "An Error Analysis in Changing Verbs to Nouns" and it conducted by Fitria (2008). In this study, she tried to find out the errors in changing verbs into nouns made by forty-two students of the eleventh year students of SMU 1 Gebog Kudus in the academic year of $2007 / 2008$. The result showed that there were 115 errors in using suffix -ance, 108 errors in using suffix - or, 107 errors in using suffix -ence, 101 errors in using suffix -ment and suffix -ant, 76 errors in using suffix -er, 59 errors in using suffix -ure and suffix -ry, 58 errors in suffix -age, 55 errors in using suffix -ion and suffix -ent, 52 errors in using suffix -ist, and 39 errors in using suffix $-a l$.

Fajrina (2014) conducted his research about a morphological analysis of derivational suffix In obama speech. The results showed two points. Firstly, There were 164 data .From the data, there were $57(34.72 \%)$ data of verb into noun, consists of suffix -ation (9 data), -ion (20 data), -er (4 data), -or (2 data), -ee (1 datum), -ing (5 data), -ment (14 data), -al (2 data). And then $23(14.01 \%)$ data of adjective into noun, consists of suffix -ness (15 data), -ity ( 8 data). Then, 6 $(3.64 \%)$ data from noun into verb, consists of suffix -ize (4 data), and -en ( 2 data). While, 37 (22.51\%) data from noun into adjective, consists of suffix -al (13 data), -ful (11), -ous (3 data), -less (4 data), -ly (2 data), -ive (2 data), -ish (1 datum) and -ic (1 datum). And then 3 (1.82\%) data from 
verb into adjective, contains of suffix -ive (1 datum), and -able (2 data). And the last is suffix ly (38 or $23.17 \%$ ) data from adjective into adverb. Secondly, suffixes -ation, -ion mean result of processes. Suffix -ing, -ment mean processes or result. Thirdly, suffix -ness, -ity mean expressing state or condition. Suffix -ee means person who do something indicated by verb. Suffix -er and or mean person or thing that do something. Suffix -al means pertaining to $\mathrm{x}$ indicated by the noun. Suffix -ize means put in the place or state indicated by the noun, and suffix -en means make more $x$. Suffix -ful means being characterized by $x$; suffix -less means without $x$; suffix - ous means having the quality of; suffix ive means having the tendency to $x$; suffix -ish means having the nature or character of $x$; and suffix -able means capable of being $x$. The last, suffix -ly means in the manner of.

Setyani (2016) made a study that was concerned with the error analysis of derivational morpheme. It aimed to find out what kinds of errors and the most frequent error in which the students made in forming derivational word. It was a descriptive qualitative research. The result showed that out of the total errors (146), the majority of errors were deriving noun from noun and adjective from verb with 30 errors. This is relevant to the questionnaire result which showed the highest percentage $(60 \%$ or 15 students) found most of students found difficulty in deriving noun from noun. The collected errors were analyzed based on the Surface Structure Taxonomy that specifies four types of errors namely omission, addition, misformation and misordering. There were 146 errors which consisted of 98 (67.1\%) misformation, 34 $(23.3 \%)$ omission, and 14 (9.6\%) addition. From the result, it can be concluded that errors were found in all categories of derivational morpheme and it was crystal clear that the most frequent errors were misformation. Therefore, the writer suggests that the students should learn and practice more in deriving morphemes.

Research conducted by Wati and Bharati (2014) the findings showed that the three teacher candidates had implemented scientific approach in their teaching speaking although there still a lot of imperfectness and it can be concluded that between 1st, 2nd, and 3rdteacher candidates, the 3rdwas the best to implement the scientific approach. The three teacher candidates also found problems in their teaching such as many students were hardly to speak English directly because of the vocabulary and lack of practice. However, both teacher candidates were able to solve the problem by peer error correction.

Rozi (2015) showed that the quality and quantity of learners' speaking skills in English improved when they practised English in a conversation lounge. Participation in the conversation lounge enhances learners' speaking skills and enriches their vocabulary, improves their pronunciation, strengthens grammar, and has a positive impact on their fluency.

\section{METHODS}

Research design in this study is qualitative research. The participants were ten Libyan students studying in three Universities in Semarang, Central Java, Indonesia; namely (Semarang State University, Diponegoro University and Sultan Agung Islamic University). The ten participants were from different majors of Master and Doctoral degrees. They can use English language in their study so they have a basic knowledge(Azwar, 2007).

In this study, the researcher used a descriptive qualitative method. In that the researcher was interested to analyze ten previous texts which were written by Libyan students from their assignments in order to explain three main points. Firstly, the errors are made by Libyan students in using derivational morphemes. Secondly, the reasons are behind these errors. Thirdly, the solutions that help them to overcome these errors from grammar point of view. It could be in the form of written forms. These forms are ten previous English texts will be taken from previous papers which were done during their assignments

\section{RESULTS AND DISCUSSION}


Based on the research result in this study, it is known that the errors made by Libyan students in Semarang city in using derivational morphemes variated, from the omission, addition, misordering and misformation, about the prefix and suffix. The error made by Libyan students such as Misformation in noun derivation "Noun to Noun", Omission in adverb derivation "Adjective to Adverb", Omission in noun derivation "Verb to Noun", Addition in adjective derivation "Noun to Adjective ", Misformation in adjective derivation "Noun to Adjective", Misordering in noun derivation "noun to noun", Misformation in adjective derivation "Adjective to Adjective", Omission in adverb derivation "adjective to adverb", Omission in verb derivation "verb to verb", Omission in adverb derivation "adjective to adverb", Misformation in noun derivation "noun to noun", Omission in noun derivation "verb to noun". The errors made in text 1 are 12 with 2 errors in the prefix and 10 errors in the suffix. The errors made in text 2 are 14 with 2 errors in the prefix and 12 errors in the suffix. The errors made in text 3 are 13 with 3 errors in the prefix and 10 errors in the suffix. The errors made in text 4 are 8 with 2 errors in the prefix and 6 errors in the suffix. The errors made in text 5 are 15 with 2 errors in the prefix and 13 errors in the suffix. The errors made in text 6 are 10 with 1 errors in the prefix and 9 errors in the suffix. The errors made in text 7 are 2 with 0 errors in the prefix and 3 errors in the suffix. The errors made in text 8 are 3 with 0 errors in the prefix and 3 errors in the suffix. The errors made in text 9 are 3 with 1 errors in the prefix and 2 errors in the suffix. The errors made in text 10 are 6 with 2 errors in the prefix and 4 errors in the suffix. From the result it also can be concluded that the majority errors is suffix rather than prefix. The most errors is the Omission in Adverb Derivation "Adjective to Adverb" and Omission in Noun derivation, adverb to Noun.

According to Haspelmath (2002, pp. 1-2) morphology is the study of internal structure of words, needs some qualification, because words have internal structure in two very different senses. The word of language can be divided into two broad categories, closed and open, of which only the latter are relevant to morphology. The closed categories are the function words, pronouns, conjunctions, determiners, and a few others. Newly coined or borrowed words cannot be added to these categories, which is why we say that they are closed. The categories of words that are open are the major lexical categories: nouns, verbs, adjectives, and adverbs. It is to these categories that new words may be added. Because the major problem of morphology is how people make up and understand words that they have never encountered before, morphology is concerned only with major lexical categories.

The lecturers have to learn more to handle the students ee errors and how to guide them to avoid the same errors. The students should learn harder. Their perception $n$ of derivational affixes should be changed. It is a way to create a good atmosphere when learning about derivation, especially derivational affixes (Parsih, 2019)

Derivational morphemes are bound morphemes or affixes which derive or create new words by either changing the meaning or the part of speech or both. English derivational morphemes can be classified into two namely derivational prefixes and derivational suffixes. Most of the English prefixes do not change part of speech although they are derivational. The derived words undergo the change of meaning. On the contrary, Most of derivational suffixes change part of speech (O'Grady, 2006). Errors are departure from the linguistic structure of the language in the massage intended to be conveyed (Sukmawati, 1995, p 23). Errors are the problems that made by Libyan students when they say or write the structures of English grammar (Amalina, 2018).

The reasons why do Libyan students make such errors because English is not their mother tongue so the Libyan students have some difficulties to speak and write derivational morphemes in English, also they are lack of practices, and the rules in English different with Arabic, lack of knowledge about derivational morphemes. Besides that, the majority that often happens to Libyans is in the mistakes that occur 
due to the first overgeneralization which causes miss spelling or misconduct mistakes that have been made but have not been corrected. Both of these false conceptual hypothesized things happen because of misunderstanding of speech because they are not familiar with English vocabulary. The three ignorance of rule restrictions are errors which they know are wrong but which make them unwilling to be corrected. Finally, the fourth is the incomplete application of rules that occurs due to lack of understanding of English vocabulary or pronunciation.

This study also in line or supported with previous study done by Agustiani (2019) it is suggested that the students should learn more about morphology especially in forming plural and learn how to construct words into phrase or clause to be a good text. It is also suggested that the lecturer should give more extra attention to those who still have difficulties in dealing with morphosyntax, and she also should give them the feedback. The difference of this study with the previous study is the samples of using Libyans students as respondents because researchers are Libyans so that the sample will be obtained more easily. The similarity in this study with the previous study is to use the descriptive analysis to reveals the error of derivational morphemes.

The novelty of this study is focused on explaining the errors made by Libyan students and explaining the reasons that are behind these errors and also explaining the solutions that help them to overcome these errors from grammar point of view and more deep understanding to the researcher sheds light on derivational morpheme.

\section{CONCLUSION}

Based on the analysis result and discussion, the conclusion of this research as follows: the majority errors is suffix rather than prefix. The most errors is the Omission in Adverb Derivation "Adjective to Adverb" and Omission in Noun derivation, adverb to Noun. The reason of Libyan student to make such error because has lack understanding about morphological rules so this make him confused all the time and make errors with derivational morphemes. This research contributes for the teaching English such as the lecturers have to learn more to handle the students' errors and how to guide them to avoid the same errors. The suggestion is the Libyan students can overcome by: read the script, then listen, more practice or thorough in vocabulary and grammar and especially in using derivational morphemes.

This study was limited for exploring the derivational morphemes errors and explaining how to use derivational morphemes during writing English texts. Therefore, for future researchers, they should focus on exploring the other linguistic errors and explaining how these linguistic errors relate to each other in using derivational morphemes during writing or speaking English texts.

\section{REFERENCES}

Azwar, S. (2007). Research Methods. Student Library.

Baayen, R. H., Feldman, L. B., \& Schreuder, R. (2006). Morphological Influences on the Recognition of Monosyllabic Monomorphemic words. Journal of Memory and Language, 55, 293-313.

Crowley, Terry, Lynch J, Siegel J, Piau J. (2005). The Design of Language An Introduction to Descriptive Linguistic: New Zealand.

Don, J. (2014). Morphological Theory and Morphology of English. Edinburgh: Edinburgh University Press.

Fitria, N. 2008. An Error Analysis in Changing Verbs to Noun (The Case of the Eleventh Year Students of SMU 1 Gebog Kudus in the Academic Year of 2007 / 2008). A final project of English Department, Languages and Arts Faculty, State University of Semarang.

Hawkins, R. (2001). Second Language Syntax: A generative Introduction. Oxford: Black-well Publisher Limited. 
Hay, J. B., \& Baayen, R. H. (2005). Shifting paradigms: Gradient structure in morphology. Trends in Cognitive Sciences, 9(7), 342-348.

Hornby, A S. (1995). “Oxford Advenced Learner's Dictionary of Current English"._London: Oxford University Press.

James, C. (1998). Errors in language learning and use. Longman

John, L. (2008). Introduction to Theoretical Linguistics. L: Cambridge University Press.

Lieber, R. (2009). Introducing Morphology. Cambridge: Cambridge University Press.

Katamba, Francis. (1993). Morphology. London: Macmillan LDT.

Katamba, Francis. (1994). Englsih Words. London: Routhladge.

Katamba, Francis. (1997). English Words. London: Combridge.

Khansir, A. A. (2012). Error analysis and second language acquisition. Theory and Practice in Language Studies, 2(5), 1027-1032.

Kinsella, (2009). Language Evaluation and Syntactic Theory. USA: Cambridge University Press.

Lieber, R. (2009). Introducing Morphology. New York: Cambridge University Press.

Littlewood, W. (1994). Foreign and second language learning: Language acquisition research and its implication for classroom. New York: Cambridge University Press, PP.44-52- 60 .

Marchand, H. (2009). The categories and types of present-day English word-formation: $A$ synchronic-diachronic approach. Munich: Beck, pp. $356 \mathrm{ff}$.

Matthews, P. H. (2011). Morphology (2nd Ed.). UK: Cambridge University Press.

Mish, Freederick. (2011). Webster Ninth New Collegiate Dictionary Springfield: Webster.

Muctar. (2007). Words, Meaning and Vocabulary: An Introduction to Modern English Lexicology. A\&C Black: England.

Mufidah. (2014). Improving Students' Ability in Using Derivational Suffixes by Using FlipAChip Technique. Semarang State University.
Nagy, W. E. and Hiebert, E. H. (2010). Toward a theory of word selection.. London: Routledge Handbook.

Nida, E. (2009). Morphology: the Descriptive Analysis of Words (Ann Arbor: University of Michigan Press).

O'Grady, W., Dobrovolsky, M., and Katamba, F. (Eds.). (2006). Contemporary linguistics. Longman.

O'Grady, W. \& Guzman, V. P. (2016). Morphology: The analysis of Word Structure. In W. O'Grady, M. Dobrovolsky, and F. Katamba (Eds.). Contemporary linguistics. London: Longman.

Parsih. (2019). “An Analysis On Students' Errors In Using Derivational Affixes". Thesis. Semarang State University.

Plag, Ingo. (2002). Word Formation in English. London: Cambridge University Press

Plag, Ingo. (2003). Word-Formation in English. New York: Cambridge University Press

Politzer, R. L. and Remirez, R. G. (2013). An Error Analysis of the spoken English of Mexican-American pupils in a bilingual school and a monolingual school. Research and Development Memorandum. 103, 1-31.

Pounder, A. (2000). Process and Paradigms in Word-Formation Morphology. Berlin: Mouton de Gruyter.

Procter, P. (2000). Longman Dictionary of Cotemporary English. England Longman Ltd.

Ramadan, S. (2015). Morphological Errors Made by Jordanian University Students. Journal of Literature, Languages and Linguistics www.iiste.org. ISSN 24228435. An International Peer-reviewed Journal Vol.14, 2015.

Rozi, Fahrur (2015). Improving Communication Skills of Tertiary Level Indonesian Learners through a Conversation Lounge. Asian EFL Journal.

Quirk, Randolph, dkk. (1985). A Comprehensive grammar of The English Language, Longman.

Robert, L. (2014). Language Teaching a Scientific Approach. New York: McGraw-Hill, Inc. 
Santi et al. (2016). Affix Errors In Short Story. Progressive Vol XI. No. 2 September 2016.

Setyani, D.P. (2016). Students' Problems In Making Derivational Words. Thesis. Semarang State University.

Setyowati, N. E. (2014). The Analysis of Derivational and Inflectional Morphemes in Lyric of Songs Adele Album. Thesis. Department of English Education, Muhammadiyah University of Surakarta

Seidenberg, M. S. \& Gonnerman, L. M. (2000). Explaining derivational morphology as the convergence of codes. Trends Cogn. Sci. 4 (9), 353-361.

Shortis, Tim. (2001). The Language of ICT: Information and Communication Technology. London: Routledge.

Sinclair, J. (1987). Collins Cobuild English Language Dictionary. London: Collins.

Spencer, Andrew. (1991). Morphological Theory. UK: Blackwell.

Spencer, P.E. (2003) Oxford Handbook of Deaf Studies, Language, and Education. New York: Oxford University Press.

Sukarni,A. (2017). Morphological Errors Made By The Sixth Semester Students of English And Literature Department of Adab And Humanities Faculty In Writing Short Paragraph. English and Literature Department Adab And Humanities Faculty, Alauddin Islamic State University of Makassar.

Sukmawati.1995. The Errors in using Classes. Makassar: Fakultas Tarbiyah. IAIN Aluddin Makassar.
Triani, F. (2009). An Analysis Of Derivational Process Of English Nouns Found In The Hello Magazine Articles. Muhammadiyah University.

Verhaar, J.W.M. (2008). Introduction to Linguistics Volume 1. Yogyakarta: Gadjah Mada University Press.

Wati, Atikah, Dwi Anggani Linggar Bharati, Rudi Hartono. (2014). The Scientific Approach In Teaching Speaking For Various Texts (The Case of Three Teacher Candidates of Wiralodra University Indramayu in The Academic Year 2013/2014). English Education Journal 4 (2).

Wehmeier, S. (2000). Oxford Advanced Learners Dictionary of Current English. Oxford: Oxford University Press.

Wulandari, A. (2014). A Morphologycal Analysis Of Derivational Suffixes In Short Stories. Muhammadiyah University, Surakarta.

Wibisono, Y. (2014). The Analysis of Morphological Errors Made by The VII Grade Students in Writing A Descriptive Paragraph at SMPN 4 Jember in The 2013/2014 Academic Year. A Thesis of Jember University

Yule, G. (2010). The Study of Language. New York: Cambridge University.

Zughoul, M. R. (2002). Interlanguage Syntax of Arabic-Speaking Learners of English: The Noun

Phrase.

ERIC. 